\title{
PEMBERDAYAAN MASYARAKAT DESA ANARAJA DALAM MENINGKATKAN SDM MELALUI PSIKOEDUKASI DAN PENDIDIKAN LINGKUNGAN BERBASIS KEARIFAN LOKAL
}

\author{
Ariswan Usman Aje ${ }^{1)}$, Lely Suryani ${ }^{2)}$, Kristianus J. Tute ${ }^{3)}$ \\ Universitas Flores ${ }^{1)}$ \\ Universitas Flores ${ }^{2)}$ \\ Universitas Flores ${ }^{3)}$ \\ ariswanusman@gmail.com
}

\begin{abstract}
ABSTRAK
Latar belakang desa Anaraja yang merupakan sebuah dusun yang baru dimekarkan dan kehidupan sosial masyarakat desa Anaraja yang masih bersifat tertutup kepada orang luar, menjadikan desa Anaraja sebagai desa yang perlu mendapakan banyak sentuhan dari berbagai pihak dalam memajukan desa tersebut. Tujuan umum dari program KKN-PPM ini adalah untuk membantu memberdayakan masyarakat agar mampu meningkatkan kualitas sumberdaya manusia Desa Anaraja Sedangkan tujuan khusus dari kegiatan ini adalah: 1) Psikoedukasi kesehatan; 2) Psikoedukasi penyuluhan dan penanganan masalah sampah lingkungan 3) Meningkatkan perekonomian masyarakat melalui pemberdayaan kelompok tenun ikat sebagai warisan budaya Lokal masyarakat desa Anaraja; 4) pemberdayaan masyarakat melalui kegiatan-kegiatan bakti sosial, pembangunan fasilitas umum seperti MCK, dan penataan desa. Adapun target dari kegiatan ini adalah melaksanakan tujuan kegiatan yang telah ditetapkan. Kegiatan pemberdayaan masyarakat agar mampu meingkatkan Sumber daya manusia dan pendidikan berbasis kearifan lokal masyarakat desa Anaraja ini dilaksanakan bersama-sama antara mahasiswa dan masyarakat disertai dengan pendamping yang ahli dibidangnya. Setelah diberikan bimbingan dan penyuluhan kegiatan KKN PPM ini berhasil meningkatkan SDM mayarakat desa Anaraja yang dilihat dari berubahnya pola fikir masyarakatnya dalam memandang lingkungan sekitar, dan pentingnya kerjasama dalam menjaga warisan budaya lokal tenun ikat yang telah ada.
\end{abstract}

Kata kunci: Psikoedukasi; Kesehatan; Lingkungan ;Kearifan Lokal

\begin{abstract}
The Anaraja village background which is a newly divided village and the social life of the Anaraja villagers who are still closed to outsiders, makes Anaraja village needs to get a lot of touches from various parties in advancing the village. The general objective of the KKN-PPM program is to help empower the community to be able to improve the quality of human resources in Anaraja Village. While the specific objectives of this activity are: 1) Health psycho-education; 2) Psychoeducation on counseling and handling environmental waste problems 3) Improving the community's economy through empowering the woven cloth as the local cultural heritage of the Anaraja village community; 4) community empowerment through social service activities, construction of public facilities such as MCK, and village management. The target of this activity is to carry out the stated objectives of the activity. Community empowerment activities in order to be able to improve human resources and education based on local wisdom Anaraja village community is carried out jointly between students and the community accompanied by an expert assistant in their field. After being given guidance and counseling PPM KKN activities succeeded in increasing the human resources of the Anaraja village community which is seen from the changing mindset of the community in looking at the surrounding environment, and the importance of cooperation in maintaining the existing local woven cloth cultural heritage.
\end{abstract}

Keywords: Psychoeducation; Health; Environment, Local Wisdom

\section{PENDAHULUAN}

Sasaran kegitan KKN-PPM ini adalah di Desa Anaraja. Desa Anaraja merupakan salah satu desa yang ada di
Kecamatan Ngangapanda Kabupaten Ende. Luas daerah nya 194,2 ha dengan jumlah penduduk Desa Anaraja berdasarkan data bulan Juli 
tahun 2019 terdiri dari 558 Jiwa dan $125 \mathrm{KK}$.

Desa Anaraja terletak di daerah pesisir pantai yang ada di kabupaten Ende. Desa ini terletak diantara kecamatan Nangapanda dan Kota Ende. Dengan batas wilayah sebagai berikut:

\section{Barat : Desa Penggajawa Kecamatan Nangapanda \\ Timur : Desa Nggorea Kecamatan Nangapanda \\ Utara : Desa Rorurea Kecamatan Nangapanda \\ Selatan: Laut Sawu}

Cakupan dusun untuk desa Anaraja sendiri adalah:

a. Dusun Ippi terdiri atas:

1. RW.01 terdiri atas; RT 01 dan RT 02

2. R.W.02 terdiri atas; RT 03 dan RT 04

b. Dusun Mbaka terdiri atas :

1. RW.03 terdiri atas; RT 05 dan RT 06

2. RW.04 terdiri atas; RT 07 dan RT 08

c. Dusun Ndeko terdiri atas ;

1. RW.03 terdiri atas; RT 09 dan RT 10

2. RW.04 terdiri atas; RT 11 dan RT 12

Berdasarkan letak wilayah desa Anaraja merupakan desa yang strategis dan mudah dijangkau karena berada tepat di pinggir jalan Negara Kabupaten Ende dan Ngada. Desa Anaraja juga berada tidak jauh dari pusat Kota Ende kurang lebih $20 \mathrm{KM}$ dan sekitar 7 KM dari ibu Kota kecamatan Nangapanda. Hal tersebut dianggap sebagai salah satu keuntungan untuk desa Anaraja sendiri dalam pengembangan perekonomian, pendidikan, kesehatan lingkungan dan lainnya. Namun sampai saat ini Desa Anaraja belum bisa mengambil keuntungan dari letak wilayah tersebut, Desa Anaraja masih membutuhkan bantuan pihak lain untuk maju melalui beragam potensi yang dimiliki desa tersebut.

Sebagian besar penduduk desa Anaraja bebersuku Flores, beragama Islam dan bermata pencaharian beragam. Dari beragam mata pencaharian yang ada sebagian besar penduduk bekerja sebagai Petani, Nelayan dan bertenun.

Berdasarkan tingkat pendidikan, masyarakat desa Anaraja dapat dikatakan memiliki tingkat pendidikan yang memadai. Tingkat pendidikan masyarakat desa Anaraja tersebar dari yang tidak tamat SD dan tidak sekolah, tingkat pendidikan dasar sampai pada jenjang pendidikan Strata 2.

Berdasarkan data yang diambil pada bulan Juli tahun 2019 tingkat pendidikan masyarakat desa Anaraja dalam prosentasi adalah sebagai berikut:

Tidak tamat SD atau tidak sekolah sebesar $19.90 \%$ atau sebanyak 111 jiwa, tamat SD sebesar 33.33\% atau sebanyak 186 jiwa, tamat SMP sebesar $16.86 \%$ atau sebanyak 94 jiwa, tamat SMA sederajat sebesar $20.07 \%$ atau sebesar 112 jiwa, tamat Diploma sebesar $1.25 \%$ atu sebanyak 7 jiwa, tamat S1 sebesar $8.42 \%$ atau sebesar 47 jiwa dan tamat S2 sebesar $0.17 \%$ atau sebanyak 1 jiwa.

Desa Anaraja merupakan sebuah dusun yang baru dimekarkan pada tahun 2013. Dengan usia yang relatif lebih muda dibanding desa lainnya diwilayah kecamatan Nangapanda membuat desa Anaraja sangat membutuhkan peran berbagai pihak dalam membangun dan menata desa Anaraja. Desa anaraja memiliki banyak potensi yang harus dikembangkan kedepannya seperti 
potensi hasil laut, wisata alam pesisir dan kain hasil tenunan ikat sebagai kearifan lokal yang masih dipertahankan dan dikerjakan oleh ibu-ibu dan remaja putri sebagai penopang perekonomian keluarga. Selain potensi yang disebutkan diatas di desa Anaraja juga terdapat sekolah mulai dari jenjang pendidikan dasar sampai pada tingkat pendidikan atas (SMA). Namun potensi yang ada tersebut belum mampu dimanfaatkan dengan baik oleh masyarakat desa Anaraja.

Banyak hal yang menjadi masalah sehingga potensi yang dimiliki desa Anaraja tersebut belum bisa dikembangkan secara maksimal. Berikut ini adalah beberapa masalah yang ada pada desa Anaraja dan masyarakatnya.

\section{Masalah Lingkungan}

Menurut Barry (Puspita, 2016:250) Salah satu hubungan antara penurunan kualitas lingkungan hidup dan manusia (sosial) yaitu sebagian besar penurunan kualitas lingkungan hidup hasil dari tindakan atau perilaku manusia. Kebiasaan membuang sampah di pesisir pantai oleh masyarakat desa Anaraja, menyebabkan turunya kualitas lingkungan pantai desa Anaraja. Pantai yang indah justru menjadi rusak akibat dari banyaknya sampah yang tidak dikelola dengan baik. Masalah ini merupakan hal yang timbul akibat perilaku masyarakat desa Anaraja sendiri. Menurut (Susilo, 2012) "Perilaku manusia dapat mengakibatkan perubahan-perubahan pada lingkungan hidup".

\section{Masalah kesehatan}

Kesehatan merupakan salah satu indikator kesejahteraan masyarakat sekaligus salah satu indikator keberhasilan pembangunan (Suharto, 2007). Generasi yang sehat merupakan generasi harapan dari sekelompok masyarakat, begitupun masyarakat desa Anaraja. Namun masih banyak masyarakat desa Anaraja yang belum memahami arti kesehatan, hal itu diakibatkan dari banyak seperti tingkat pendidikan dan perilaku masyarakat yang minim di bidang kesehatan, faktor lingkungan, faktor pelayanan kesehatan dan lainnya.

Menurut Notoatmodjo (2007: 11-13), terdapat empat faktor yang mempengaruhi kesehatan. Faktorfaktor tersebut adalah faktor lingkungan (mencakup lingkungan fisik, sosial, budaya, politik, ekonomi, dan lain sebagainya), perilaku, pelayanan kesehatan, dan hereditas (keturunan).

\section{Masalah Ekonomi}

Telah disebutkan bahwa menenun merupakan pekerjaan pendukung yang dilakukan oleh ibubu dan remaja putri masyarakat Anaraja dalam meningkatkan perekonomian keluarganya. Pekerjaan menenun oleh ibu-ibu, selain untuk membantu perkonomian, juga sebagai bentuk untuk menjaga kelestarian budaya masyarakat Ende. Hampir semua ibu-ibu rumah tangga dapat melakukan pekerjaan menenun. Adanya aturan dari Pemda, maupun instansi swasta yang mengharuskan pegawainya mengenakan pakaian motif daerah, menjadikan hasil tenun ikat sebagai suatu potensi unggulan yang apabila dikemas dengan baik dapat membawa perubahan yang sangat besar terhadap perekonomian masyarakat desa Anaraja Khususnya masyarakat perajin tenun ikat. Sayangnya prospek menjanjikan pada pekerjaan menenun tidak dibarengi 
dengan pengelolaan dan pemberdayaan yang baik seperti pada promosi dan pemasaran. Selain itu masyarakat desa Anaraja juga masih memiliki pola pikir bahwa Pekerjaan menenun masih dianggap sebagai pekerjaan sampingan. Masalah tersebut juga ditambah dengan belum adanya upaya pemerintah dalam melakukan pemberdayaan masyarakat penenun khususnya di desa Anaraja.

Sedangkan isu-isu utama yang menjadi permasalahan pokok yang terjadi di masyarakat yang pemecahannya perlu diprioritaskan dapat dikelompokkan menjadi beberapa isu seperti isu Pendidikan lingkungan, Kesehatan, perekonomian desa, serta sosial masyarakat dan pembangunan desa.

Berdasarkan uraian awal di atas untuk menyelesaikan masalah yang di hadapi oleh masyarakat Desa Anaraja, maka solusi penyelesaian masalah yang dapat diambil dalam kegiatan KKN-PPM di desa Anaraja antara lain sebagai berikut:

\section{Psikoedukasi Kesehatan}

Menurut Rachmaniah (2012) Psikoedukasi adalah pengembangan dan pemberian informasi yang berbentuk pendidikan pada masyarakat tentang informasi yang berkaitan dengan psikologi populer atau informasi tertentu yang digunakan untuk mempengaruhi kesejahteraan psikososial masyarakat. Kegiatan psikoedukasi ini dilakukan dengan cara memberikan edukasi tentang pentingnya kesehatan dan tumbuh kembang anak. Penyuluhan ini dilakukan bidan Desa sebagai tenaga ahli bidang kesehatan dan mahasiswa KKN PPM sebagai pendamping dan penyelenggara kegiatan.
2. Penyuluhan tentang pentingnya pelestarian lingkungan, pengelolaan sampah dan sanitasi lingkungan.

Dalam penyuluhan ini juga dilakukan diskusi bersama warga untuk menentukan mekanisme terbaik dari pengelolaan sampah berbasis masyarakat. Penyuluhan ini akan dilakukan dengan bekerja sama dengan ACIL (Anak CInta Lingkungan) Ende. Anggota ACIL dan Mahasiswa juga masyarakat setempat akan melakukan penanaman pohon waru di sepanjang Pantai.

3. Pemberdayaan ibu-ibu dan remaja putri dalam mendukung pelestarian kearifan lokal tenun ikat sebagai penyokong perekonomian keluarga.

Pemberdayaan ibu-ibu dan remaja putri ini dilakukan sebagai upaya untuk menjaga warisan budaya sekaligus sebagai penyokong utama perekonomian keluarga. Pemberdayaan ini dilakukan dengan mendata dan membentuk kelompok tenun ikat di tiga dusun yang berada diwilayah desa Anaraja. Masingmasing dusun dibentuk satu kelompok sebagai contoh. Dengan pembentukan kelompok diharapkan hasil yang dikerjakan bisa lebih maksimal dan waktu yang digunakan bisa lebih efisien karena dikerjakan secara bersama-sama. Kelompok-kelompok ini juga diharapkan menjadi cikal bakal kelompok usaha rumah tangga.
4. Pemberdayaan masyarakat dalam membangun dan menata desa melalui pembanngunan fisik.

Pada kegiatan ini masyarakat diberdayakan dalam kegiatan membangun dan menata desa. Desa sebagai tempat tinggal menjadi miliki 
bersama, segala fasilitas umum mesti ditata dan dikelola secara bersamasama untuk kemajuan desa. Dalam pembangunan fisik fasilitas umum seperti MCK, masyarakat akan dilibatkan secara aktif. Dengan melibatkan masyarakat dalam kegiatan ini, diharapkan rasa memiliki, semangat gotong royong, tanggung jawab akan sama-sama dirasakan oleh setiap masyarakat desa Anaraja. Selain itu MCK dibangun sebagai solusi dalam menangani masalah BAB masyarakat Anaraja. Selain pembangunan fasilitas umum seperti MCK bantuan lain penataan ruang desa adalah pembuatan batas wilayah desa dan dusun.

5. Penanaman pohon waru dan pohon tanjung sekaligus pembersihan wilayah pantai desa Anaraja.

Penanaman pohon waru dan pohon tanjung sebagai kegiatan penghijauan desa Anaraja. Kegiatan ini sekaligus bagian dari penanaman karakter cinta lingkungan dan menjaga kebersihan lingkungan sekitar. Penanaman pohon waru disepanjang pantai anaraja juga sebagai bentuk pendukung dalam menata wilayah pantai menjadi lebih indah. Kegiatan ini akan dilakukan mahasiswa KKN PPM bersama dengan komunitas ACIL Ende, dan masyarakat desa Anaraja.

6. Kegiatan-kegiatan penunjang lain yang dilakukan Mahasiswa KKN PPM

Kegiatan lain yang dilakukan mahasiswa selama kegiatan KKN PPM adalah kegiatan penunjang. Adapun kegiatan penunjang tersebut dilakukan sebagai pendukung kegiatan utama diatas. Kegiatan penunjang tersebut seperti, bimbingan belajar kepada anak-anak sekolah desa Anaraja, bakti sosial bersama masyarakat, terlibat dalam membantu administarasi dikantor desa, melakukan pendataan penduduk, mempelopori kegiatan perayaan tujuh belas agustus sebagai bentuk penanaman semangat nasionalisme dan cinta tanaha air.

Adapaun target dan luaran yang diharapkan dapat tercapai dari pelaksanan kegiatan KKN PPM ini adalah sebagai berikut:

1. Mahasiswa dapat menjadi agen perubahan bersama Dosen Pembimbing Lapangan (DPL) dalam meningkatkan pengetahuan masyarakat desa Anaraja

2. Psikoedukasi kesehatan yang diberikan dapat berjalan dengan baik, dan diharapkan setelah adanya sosialisasi kesehatan dapat membawa perubahan kepada masyarakat desa Anaraja agar lebih serius memperhatikan masalah kesehatan khususnya kesehatan ibu dan anak

3. Psikoedukasi lingkungan dapat berjalan dengan baik serta diharapkan setelah adanya sosialisasi tentang kebersihan lingkungan dapat membawa perubahan cara pandang masyarakat anaraja tentang pentingnya lingkungan yang bersih dan nyaman.

4. Dapat membentuk minimal tiga kelompok tenun ikat dari perwakilan masing-masing dusun dan menjadi contoh dalam mengembangkan usaha tenun ikat sebagai penyokong ekonomi keluarga

5. Meningkatnya pendapatan dari usaha kelompok tenun ikat di desa Anaraja

6. Masyarakat desa anaraja dapat menerima dan mengikuti semua program KKN PPM dengan baik. 
7. Dapat meningkatkan semangat kerjasama dan gotong royong melalui pekerjaan-pekerjaan fisik dalam program KKN PPM.

\section{METODE PELAKSANAAN}

Metode yang digunakan dalam pelaksanan KKN PPM ini adalah melalui kegiatan penyuluhan (penyadaran dan peningkatan pemahaman masyarakat melalui psikoedukasi), Pemberdayaan dan pembangunan fisik. Pelaksanaan kegiatan KKN PPM ini diawali dengan survey lokasi KKN, penentuan lokasi, perekrutan dan pengalokasian mahasiswa. Untuk kegiatan KKN PPM ini dilaksanakan di desa Anaraja dengan jumlah mahasiswa sebanyak 20 orang dengan rincian 12 mahasiwa dan 8 Mahasiswi. Kegiatan KKN PPM ini dibimbing oleh tiga dosen pembimbing lapangan dengan diketuai oleh pak Ariswan Usman Aje, M.Pd dan dua Anggota yakni ibu Lely Suryani, B.A., M.A dan pak Kristianus J.Tute, M.Pd. Kegiatan KKN PPM ini di laksanakan selama 6 minggu, dimulai dari tanggal 29 Juli sampai tanggal 7 September 2019.

Sebelum pemberangkatan kelokasi KKN PPM terlebih dahulu dilakukan pembekalan kepada mahasiswa dan mahasiswi peserta KKN PPM baik dari universitas maupun dari dosen pembimbing lapangan sebagai bentuk penyatuan persepsi pelaksanaan kegiatan $\mathrm{KKN}$ PPM.

Sesuai dengan tema kegiatan yaitu Pemberdayaan Masyarakat dalam meningkatan Sumberdaya Manusia melalui Psikoedukasi dan Pendidikan Lingkungan Bebasis Kearifan Lokal pada Masyarakat Desa Anaraja, maka kegiatan yang akan dilakukan mahasiswa adalah yang akan memberi dampak pada masyarakat, lingkungan dan ekonomi. Pelaksanaan kegiatan dibantu oleh Dosen Pembimbing Lapangan (DPL).

Berikut ini adalah diagram alir dari pelaksanaan kegiatan KKN-PPM:

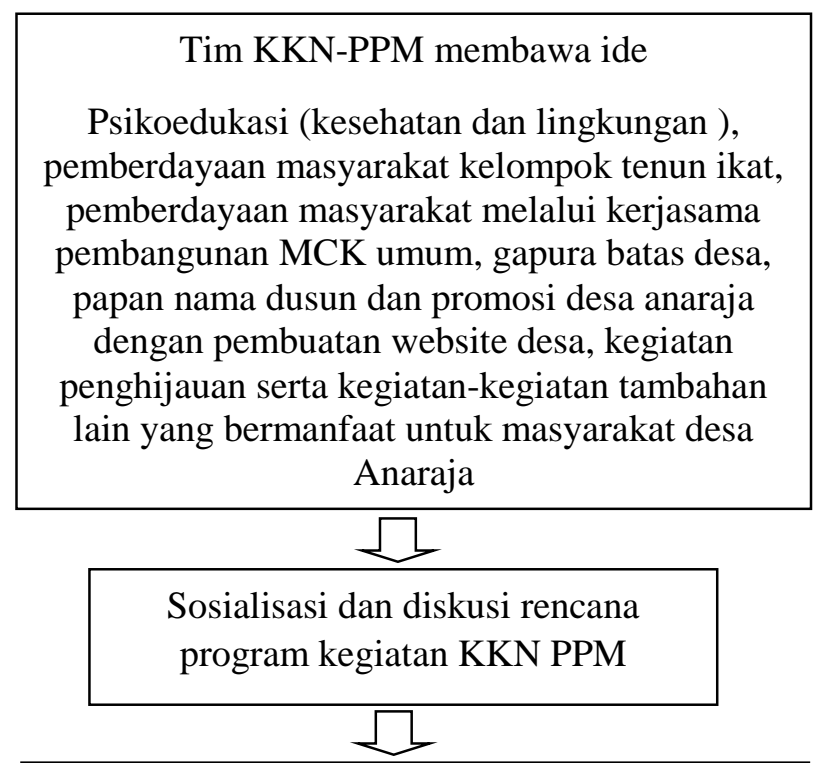

Pemerintah desa dan Masyarakat desa Anaraja menyambut baik dan menyatakan kesiapan dan keterlibatan dalam penyelesaian rencana kegiatan KKN PPM

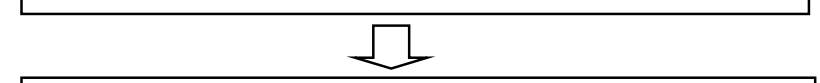

Penetapan jadwal Psikoedukasi Lingkungan dan kesehatan, Penetapan lokasi pembangunan fasilitas umum MCK, Gapura batas desa dan papan nama batas dusun, pembentukan kelompok tenun ikat dan penetapan lokasi penghijauan

Pelaksanaan kegiatan bersama-sama Mahasiswa KKN PPM dan Masyarakat desa Anaraja

Gambar 1. Diagram Alir Kegiatan KKN PPM desa Anaraja

\section{HASIL DANPEMBAHASAN}

Selama enam pekan Pelaksanaan KKN PPM telah banyak kegiatan yang dijalankan sesuai dengan rencana dan 
target yang telah diteatapkan sebelumnya. Pelaksanaan kegiatan dibagi menjadi dua bagian yakni kegiatan-kegiatan utama dalam pelaksanaan KKN PPM dan kegiatankegitan pendukung lainnya berkut:

1. Kegiatan-kegiatan Utama

$$
\begin{aligned}
& \text { a. Kegiatan psikoedukasi } \\
& \text { pendidikan lingkungan }
\end{aligned}
$$

Materi pelaksanaan kegiatan psikoedukasi pendidikan lingkungan ini disampaikan oleh ketua komunitas Anak Cinta Lingkungan kabupaten Ende. Kegiatan ini dihadiri oleh bapak kepala desa Anaraja, perangkat desa, mahasiswa KKN PPM desa Anaraja, masyarakat desa Anaraja dan para undangan lainnya. Tema kegiatan adalah Lingkungan dengan isu permasalahan yang diangkat adalah Sampah, Masalah dan Solusinya.

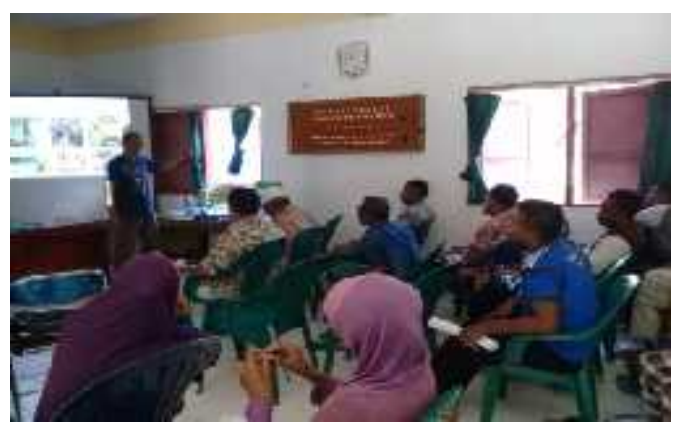

Gambar 2. Kegiatan Psikoedukasi Lingkungan

\section{b. Kegiatan Psikoedukasi Kesehatan}

Materi Pelaksanaan kegiatan Psikoedukasi kesehatan ini disampaikan oleh Bidan desa Anaraja sebagai tenaga ahli dibidang kesehatan. Sasaran kegiatan ini adalah masyarakat desa Anaraja khususnya anak-anak, balita dan ibu-ibu hamil. Kegiatan ini juga dihadiri oleh bapak kepala desa dan perangkat, masyarakat sasaran dan mahasiswa KKN PPM desa Anaraja. tema umum kegiatan ini adalah kesehatan masyarakat dengan isu yang diangkat adalah tentang tumbuh kembang anak dan kesehatan ibu hamil.

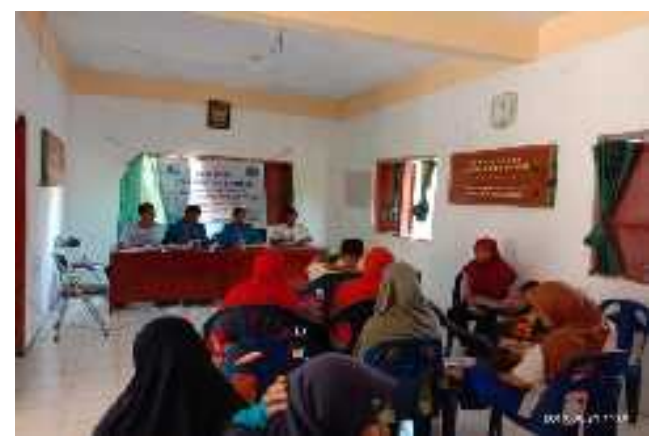

Gambar 3. Psikoedukasi Kesehatan

$$
\begin{aligned}
& \text { c. Pemberdayaan kelompok } \\
& \text { penenun masyarakat desa } \\
& \text { Anaraja. }
\end{aligned}
$$

Pemberdayaan kelompok masyarakat penenun diawali dengan pembentukan kelompok tenun ikat. Pembentukan kelompok tenun ikat secara resmi berdasarkan surat keputusan kepala desa Anaraja. Berdasarkan hasil diskusi dengan masyarakat disepakati kelompok yang dibentuk sebanyak tiga kelompok dengan perwakilan dari masingmasing dusun. Setiap kelompok diberikan bantuan stimulan berupa bahan tenun ikat. Bantuan tersebut deberikan sebagai bukti keseriusan dari pelaksanaan KKN PPM dan sebagai motivasi kepada kelompok untuk bekerja secara sungguh-sungguh dan bersama-sama. Selain itu dalam kegiatan pemberdayaan ini juga dilakukan bimbingan dan pendampingan serta penanaman jiwa kewirausahaan khususnya dalam usaha kerajinan tenun ikat.

\section{d. Pembuatan website desa}

Website dibuat sebagai bagian promosi desa Anaraja. Website ini dibuat oleh mahasiswa dan dosen pendamping KKN PPM. Selanjutnya diberikan pelatihan kepada perangkat desa dalam menggunakan website 
untuk mempromosikan desa Anaraja, seperti promosi desa wisata, hasil kerajinan tenun ikat, hasil laut dan potensi lainnya dari desa Anaraja.
e. Pemberdayaan masyarakat desa melalui pekerjaan- pekerjaan fisik

Pekerjaan fisik yang dilakukan adalah pembangunan sebuah MCK, gapura batas desa, papan nama dusun, dan fasilitas tempat sampah dari bambu.

\section{f. Kegiatan penghijauan}

Diakhir kegiatan KKN PPM mahasiswa bersama komunitas ACIL kabupaten Ende, dan masyarakat desa melakukan bakti sosial dan penghijauan disepanjang bibir pantai desa Anaraja. Pada pelaksanaannya kegiatan ini dihadiri oleh TNI (KODIM 1602) Ende dan FORKOMPINDA (Pimpinan daerah kabupaten Ende).

\section{Kegiatan Tambahan}

Selain kegiatan-kegiatan yang telah diprogramkan dalam kegiatan KKN PPM ini, pada pelaksanaannya dilapakan terdapat beberapa kegiatan yang dilakukan oleh mahasiswa KKN PPM. Kegiatan-kegiatan tersebut seperti; 1) Kegiatan bimbingan belajar, sasaran kegiatan ini adalah anak-anak sekolah usia SD dan SMP yang ada di desa Anaraja, 2) Kegiatan Aneka perlombaan dalam merayakan HUT kemerdekaan RI yang ke 74 Tahun. Kegiatan ini dilakukan untuk menanamkan nilai-nilai perjuangan kepada masyarakat desa Anaraja. Kegiatan ini juga bertujuan untuk mempererat silahturahmi antar sesama masyarakat desa Anaraja dan juga mahasiswa KKN PPM. Aneka perlombaan yang sifatnya hiburan dianggap sebagai bentuk yang cocok dalam mempererat hubungan tersebut.
Adapun beberapa hasil yang dicapai dalam pelaksanaan KKN PPM di desa Anaraja tahun 2019 adalah tercapainya target-target kegiatan KKN PPM. Adapun hasil tersebut dapat kami rangkum sebagai berikut:

1. Mahasiswa dapat menjadi agen perubahan bersama Dosen Pembimbing Lapangan (DPL) dalam meningkatkan pengetahuan masyarakat desa Anaraja.

2. Psikoedukasi kesehatan yang diberikan dapat berjalan dengan baik, dan diharapkan setelah adanya sosialisasi kesehatan dapat membawa perubahan kepada masyarakat desa Anaraja agar lebih serius memperhatikan masalah kesehatan khususnya kesehatan ibu dan anak. Peningkatan pemahaman masyarakat akan kesehatan sebesar $30 \%$ dari sebelumnya $65 \%$ menjadi $95 \%$

3. Psikoedukasi lingkungan dapat berjalan dengan baik serta diharapkan setelah adanya sosialisasi tentang kebersihan lingkungan dapat membawa perubahan cara pandang masyarakat anaraja tentang pentingnya lingkungan yang bersih dan nyaman. Hal ini terlihat dari hasil quisioner yang diberikan dimana terdapat peningkatan pemahamana masyarakat dalam pengelolaan dan pemanfaatan sampah sebesar $40 \%$ yang sebelumnya $50 \%$ menjadi $90 \%$

4. Dapat membentuk minimal tiga kelompok tenun ikat dari perwakilan masing-masing dusun dan menjadi contoh dalam mengembangkan usaha tenun ikat sebagai penyokong ekonomi keluarga. Hal ini karena sebelumnya belum ada usaha tenun ikat dalam bentuk kelompok.

5. Meningkatnya pendapatan, efisiensi waktu dan semangat usaha bersama dari usaha kelompok tenun 
ikat di desa Anaraja. Rata-rata peningkatan pendapatan kelompok tenun sebesar $80 \%$.

6. Masyarakat desa anaraja dapat menerima dan mengikuti semua program KKN PPM dengan baik.

7. Dapat meningkatkan semangat kerjasama dan gotong royong melalui pekerjaan-pekerjaan fisik dalam program KKN PPM.

Selain hasil-hasil yang dicapai dari target yang telah ditetapkan, KKN PPM desa Anaraja juga memberikan hasil lain dari kegiatan-kegiatan tambahan pelaksanaan KKN yang antara lain dapat kami rangkum sebagai berikut:

1. Kegiatan bimbingan belajar kepada anak sekolah desa Anaraja, memberikan dampak yang baik bagi anak sekolah dalam membangkitkan semangat belajar kepada anak sekolah.

2. Kegiatan perlombaan menyambut HUT kemerdekaan RI yang ke 74 dapat memberikan semangat perjuangan dan kebersamaan bagi masyarakat desa Anaraja

3. Keberadaan mahasiswa dalam kegiatan sehari-hari masyarakat desa Anaraja dapat membuka hubungan sosial antara masyarakat desa Anaraja dan dunia luar.

\section{KESIMPULAN}

\section{Simpulan}

a. Pelaksanaan kegiatan KKN PPM dilaksanakan selama 6 minggu dan dilakukan di desa Anaraja. Kegiatan ini dapat berjalan dengan baik berkat keterlibatan berbagai pihak seperti Ristekdikti, Lembaga perguruan tinggi Universitas Flores, LP2M, dan P3KKN Universitas Flores, Mahasiswa
KKN PPM desa Anaraja 2019 serta Masyarakat dan perangkat desa Anaraja

b. Tercapainya target-target yang telah ditetapkan dalam kegiatan KKN PPM desa Anaraja tahun 2019.

\section{Saran}

Program-program dalam kegiatan ini sebaiknya harus ditindaklanjuti melalui pembinaan, pembimbingan dan pendampingan secara terus menerus dalam meningkatkan sumberdaya manusia masyarakat desa khususnya desa Anaraja.

\section{Ucapan Terimakasih}

Pelaksanaan kegiatan KKN PPM ini tidak lepas dari bantuan dari berbagai pihak, untuk itu kami sebagai tim pengabdian mengucapkan rasa terimakasih yang sebesar-besarnya kepada :

1. DRPM Ristekdikti yang telah membiayai pelaksanaan kegiatan KKN PPM di desa Anaraja ini tahun 2019

2. Lembaga Perguruan Tinggi Universitas Flores yang telah mendukung pelaksanaan kegiatan KKN PPM ini

3. LP2M Universitas Flores

4. P3KKN Universitas Flores

5. Organisasai ACIL Ende

6. Kepala desa, Perangkat desa dan masyrarakat desa Anaraja

7. Mahasiswa - Mahasiswi peserta KKN PPM desa Anaraja tahun 2019. 


\section{REFERENSI}

Notoatmodjo, Soekidjo. (2007). Promosi Kesehatan dan Ilmu Perilaku. Jakarta: Rineka Cipta.

Puspita, Ibrahim, Hartono. (2016). Pengaruh Perilaku Masyarakat Yang Bermukim Di Kawasan Bantaran Sungai Terhadap Penurunan Kualitas Air Sungai Karang Anyar Kota Tarakan. Jurnal Manusia Dan Lingkungan, Vol. 23, No.2, Juli 2016: 249-258.

Rachmaniah, D. (2012). Pengaruh Psikoedukasi Terhadap Kecemasan dan Koping Orang Tua dalam Marawat Anak dengan Thalasemia Mayor di RSU Kabupaten Tangerang Banten. Universitas Indonesia: Tesis.

Rencana Pembangunan Jangka Menengah Desa. (2018). (RPJM Desa Anaraja).

Suharto, Edi. 2007. Kebijakan Sosial sebagai Kebijakan Publik. Bandung: Alfabeta.

Susilo, R.K.D., 2012. Sosiologi Lingkungan. PT. Rajagrafindo Persada. Jakarta. 